\title{
Budgeting practices: a study on Brazilian hotel companies
}

\author{
Práticas de orçamento: um estudo em empresas hoteleiras do Brasil \\ Prácticas de presupuesto: un estudio en empresas hoteleras en Brasil
}

\author{
Paula de Souza ${ }^{1}$ \\ Rogério João Lunkes ${ }^{2}$
}

\begin{abstract}
Resumo: O presente estudo tem como objetivo explorar as práticas orçamentárias em empresas hoteleiras dos principais centros turísticos do Brasil. A justificativa se orienta na quantidade de turistas estrangeiros recebidos pelos dez principais destinos turísticos brasileiros, que atinge $95 \%$ do país. Outra motivação é a carência de pesquisas em empresas hoteleiras nos países em desenvolvimento, devendo ser considerado também que o Brasil sediará a Copa do Mundo em 2014 e os Jogos Olímpicos em 2016, o que requer uma estrutura hoteleira adequada para receber um grande número de atletas e turistas. Assim, para atingir o objetivo deste estudo, foram enviados questionários aos hotéis associados à Associação Brasileira da Indústria de Hotéis (ABIH), recebendo retorno de 40 empresas hoteleiras. A estatística descritiva foi aplicada sobre os resultados, com a finalidade de melhorar a base das discussões. Os resultados apontam que a maioria dos hotéis adota o orçamento empresarial, tendo o bottom-up como processo orçamentário predominante. A pesquisa mostra que os orçamentos são elaborados, com maior frequência, utilizando-se os resultados de anos anteriores e indicadores econômicos. Na avaliação de desempenho, são frequentemente aplicadas a análise comparativa, a análise das causas dos desvios e as medidas de adequação. A análise das variações estão principalmente direcionadas para o controle dos custos/despesas, a identificação de problemas potenciais e o fornecimento de feedback para o próximo período.
\end{abstract}

Palavras-chave: Orçamento. Planejamento. Execução. Controle. Hotel.

Abstract: This study aims to explore the budgeting practices in the hotel companies of Brazil's main tourist centers. The justification is oriented by the number of foreign tourists received by the top ten Brazilian tourist destinations, which reaches $95 \%$ of the country. Another motivation is the lack of research on hotel companies in developing countries, and it should also be considered that Brazil will host the World Cup in 2014 and the Olympic Games in 2016, which requires a suitable hotel structure to receive a large number of athletes and tourists. Thus, in order to achieve the purpose of this study, surveys were sent to the hotels associated with the Brazilian Association of the Hotel Industry $(A B I H)$, with replies by 40 hotel companies. Descriptive statistics were applied to the results, in order to improve the basis for discussions. The results indicate that most of the hotels adopt corporate budgeting with bottom-up as main budgeting process. Research shows that budgets are developed, more frequently, using the results from previous years and economic indicators. In the performance evaluation, the comparative analysis, the analysis of the causes of deviations and adequacy measures are often applied. The analysis of variance is primarily directed at controlling costs/expenses, identifying potential problems and providing feedback for the next period.

Keywords: Budget. Planning. Execution. Control. Hotel.

1 Universidade Federal de Santa Catarina - UFSC Mestre em Contabilidade (PPGC/UFSC) - Contadora (CRC/SC 37.543/O-5) pauladesouza1604@gmail.com.

2 Universidade Federal de Santa Catarina - UFSC- Doutor em Engenharia de Produção pela Universidade Federal de Santa Catarina (2003). Pós-doutor pela Universidad de Valéncia-Espanha (2011). Atualmente é docente do Programa de Pós-graduação em Contabilidade da Universidade Federal de Santa Catarina. rogerio.lunkes@ufsc.br. 
Resumen: Este estudio tiene como objetivo explorar las prácticas presupuestarias en las empresas hoteleras de los principales centros turísticos de Brasil. La razón fundamental se orienta en el número de turistas extranjeros recibidos por los diez destinos turísticos brasileños, que alcanza el 95 \% del país. Otra motivación es la falta de investigación en la industria hotelera en los países en desarrollo y se debe considerar también que Brasil será sede de la Copa del Mundo en 2014 y los Juegos Olímpicos de 2016, que exige una adecuada infraestructura hotelera para recibir un gran número de atletas y turistas. Por lo tanto, para lograr el objetivo de este estudio, se enviaron cuestionarios a los hoteles asociados a la Asociación Brasileña de la Industria Hotelera (ABIH), la recepción de retorno de 40 empresas hoteleras. Estadística descriptiva se aplicaron a los resultados con el fin de mejorar la base para la discusión. Los resultados muestran que la mayor parte del negocio de hoteles adopta presupuesto con la de abajo hacia arriba como el proceso presupuestario predominante. La investigación muestra que se desarrollan los presupuestos, con más frecuencia, el uso de los resultados de años anteriores y los indicadores económicos. En la evaluación del desempeño, a menudo se aplica a un análisis comparativo, el análisis de las causas de las desviaciones y la adecuación de las medidas. El análisis de las variaciones se dirigen principalmente a controlar los costos/gastos, identificar problemas potenciales y proporcionar información para el próximo período.

Palabras clave: Presupuesto. Planificación. Ejecución. Control. Hotel.

\section{INTRODUCTION}

The budget is seen as the "backbone" of organizations in measuring performance (Jones, 2008a). Furthermore, it is considered one of the mechanisms most employed by managers in controlling costs and improving performance (Kin; Clarkson \& Wallace, 2010) as well as operations management (Szychta, 2002; Abdel-Kader \& Luther, 2006; Uyar, 2009; Sivabalan et al.,2009; Libby \& Lindsay, 2010).

Even with great use in business, often budgeting is also criticized. Some authors argue that budget problems are related to the way it is used (Horngren; Foster \& Datar, 2000), while others affirm that budgetary processes are essentially flawed (Hope; Fraser \& Rosen, 2003; Hansen; Otley $\&$ Van Der Stede, 2003). For Jones (2008a), these affirmations present different aspects, but also share many of the concerns inherent to corporate budget. Nevertheless, this budget continues to be widely used in organizations (Jones, 2008a; Uyar \& Bilgin, 2011, Castro et al., 2012).

If there is anything in common in these debates is the perceived need to make the most effective and efficient budgeting process in organizations, seeking more benefits (Uyar \& Bilgin, 2011). This gain in efficiency can be gained from changes in the forms and practices applied to planning, execution and control of the budget. Research by Umapathy (1987) and King, Clarkson \& Wallace (2010) confirmed that successful companies, in fact, adopted some practices that made their budget systems more effective. Among the practices highlighted in the studies are the generation of commitment, the alignment between levels of the organization, the adoption of detailed and comprehensive procedures in the preparation and analysis of variations, and taking corrective actions.

The important point is that there is a need to improve the efficiency of the budgeting process, in order to obtain more benefits (Uyar \& Bilgin, 2011). Although the budget is often studied (Castro et al., 2012), due to its practical importance, it needs to be researched more widely, especially in the service sector (Uyar \& Bilgin, 2011). 
Recent studies highlighted the lack of research on budgeting practices in hotel companies (Steed \& Gu, 2009; Uyar \& Bilgin, 2011), especially in developing countries such as Brazil. Furthermore, the hotel industry is one of the most important in the service sector in many countries, including Brazil, which in 2012 received 5.67 million foreign tourists, surpassing the marks of 5.4 million in 2011 and 52 million in 2010, representing 5\% of the national GDP. The services better evaluated by them were hospitality (97.7\%), food (95.5\%) and accommodation (93.2\%) (Ministry of Tourism, 2013).

In this sense, in order to achieve the goal of exploring the budgeting practices in the hotel industry of the main tourist centers of Brazil, the questionnaire was based on several previous studies in the United States (Schmidgall \& DeFranco, 1998; Steed \& Gu, 2009), the United States and Scandinavia (Schmidgall; Borchgrevink \& Zahl-Begnum, 1996), the United Kingdom and the United States (Jones, 1998; Jones, 2008a, b), Australia (Subramaniam; McManus \& Mia, 2002; Winata \& Mia, 2005) China (Yuen, 2006), Greece (Pavlatos \& Paggios, 2009) and Turkey (Uyar \& Bilgin, 2011).

The top ten tourist destinations - Rio de Janeiro (RJ), Florianópolis (SC), São Paulo (SP), Salvador (BA), Foz do Iguaçu (PR), Balneario Camboriu (SC), Porto Alegre (RS), Recife ( $P E$ ), Fortaleza (CE) and Buzios (RJ) - are the subject of this study and together receive $95 \%$ of foreign tourists in the country (Ministry of Tourism, 2010). These data show the importance of such tourist centers for Brazil and, therefore, deserve to be studied.

Another motivation is the lack of research on hotel companies in developing countries, and it should also be considered that Brazil will host the World Cup in 2014 and the Olympic Games in 2016, which requires a suitable hotel structure to receive a large number of athletes and tourists.

\section{LITERATURE REVIEW}

\subsection{Planning and Budget Preparation}

The budget manual includes the guidelines, goals, targets and indicators agreed by senior management. The study by Uyar \& Bilgin (2011) on hotel companies in Turkey reveals that $63 \%$ prepare budget manuals, which corroborates the research by Steed \& Gu (2009), who noted the establishment of the budget guidelines by senior management in an average 4.5 points on a scale of one to five.

Among the type of indicator used, Schmidgall, Borchgrevink \& Zahl-Begnum (1996) found that $58.5 \%$ and $52.5 \%$ of the hotels in Scandinavia and the United States set a financial goal. In Scandinavian hotel companies, the most important financial goal is net income for $51.5 \%$ of the hotels, the return on owner's equity for $15.5 \%$, the cash flow for $6.1 \%$, and some other financial objective for $27.2 \%$. These other financial goals include the gross operating income necessary to cover the cost of capital investment profits. In hotels in the U.S., the most important financial goal is net income for $65 \%$, cash flow for $16.7 \%$ and some other financial goal for $11.7 \%$ of hotel com- 
panies. Thus, it can be seen that for both groups of hotels, net income is clearly the number one priority.

The budget committee is a committee formed to guide the planning, implementation and control process, and may include owners, directors and general managers, chief financial officer, department heads, controller and so on. The results of the study by Uyar \& Bilgin (2011) showed that $87 \%$ have a budget committee. The coordinator responsible for the preparation of the budget in the United States, according to Schmidgall, Borchgrevink \& Zahl-Begnum (1996), is the controller in $67.8 \%$, the general manager in $26.4 \%$, assistant manager in $12.5 \%$ and others in $3.3 \%$ of cases. Now in Scandinavia, the main responsible is the general manager in $57.4 \%$ of the hotels, the controller in $33.3 \%$, assistant manager in $1.9 \%$ and others in $7.4 \%$.

Moreover, the research by Uyar \& Bilgin (2011) in Turkey found that $65 \%$ of participants of the committee were general managers, $61 \%$ controllers or accounting managers, $39 \%$ managers and financial officers, $31 \%$ marketing managers, $22 \%$ personnel managers and $8 \%$ others. The average number of participants is 3.09 people per committee.

The time of preparation of the budget relates to the period to draw up the budget process. In research conducted by Uyar \& Bilgin (2011), most companies, about $80 \%$, take around one to two months to prepare their annual budget. The study by Steed \& Gu (2009) revealed that $15 \%$ of hotels in the United States spend less than 40 hours, $27.5 \%$ between 40 and 80 hours, $27.5 \%$ between 81 to 120 hours and $30 \%$ take over 120 hours .

The forms of budgeting may involve mainly three types: top-down and bottom-up combination. In top-down, the budget is prepared by senior management and imposed on other members of the organization. In bottom-up, the budget is prepared by the responsible centers or departments and submitted to senior management for approval. In combination, the budget is prepared through an interactive process between responsible centers and senior management. Table 1 presents the main forms of budgeting in different studies.

Table 1- Forms of preparing the budgeting process (in percentage)

\begin{tabular}{|c|c|c|c|c|c|c|c|c|}
\hline & 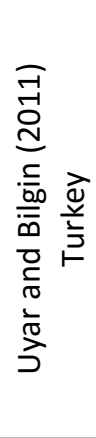 & 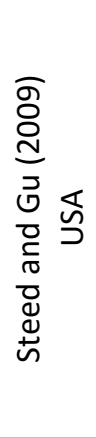 & 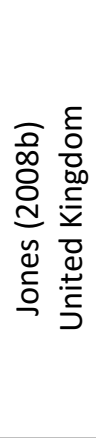 & 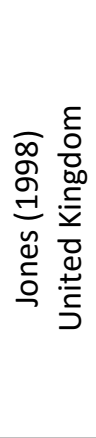 & 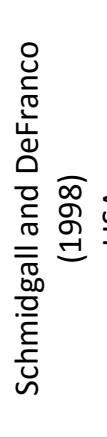 & 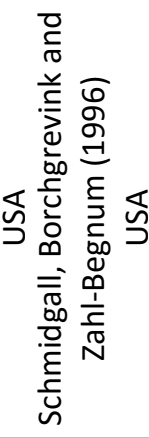 & 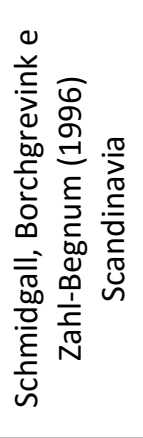 & 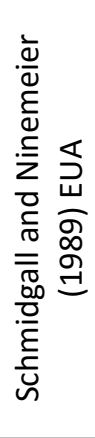 \\
\hline Top-down & 24 & 2.4 & 26 & 13.6 & 4.5 & 4.5 & 4 & 13.3 \\
\hline Bottom-up & 34 & 16.7 & 36 & 54.6 & 64 & 79.5 & 64 & 56.7 \\
\hline Combination & 42 & 78.6 & 39 & 31.8 & 28 & 16 & 28 & 26.7 \\
\hline Others & & & & & & 0 & 4 & \\
\hline
\end{tabular}

Source: Review data

One of the most important forecasts of budgeting is the revenue. Among the main areas of 
study are the basis for establishing revenue growth.

The study by Steed \& Gu (2009) showed that in $64.3 \%$ of hotel companies, the value indicated by the hotel owner was the most important influence in the guidelines for increasing revenue. Among the bases for such an increase, stand out REVPAR or increased percentage with $54.8 \%$, percentage of increase over the previous year with $52.4 \%$, based on ADR and occupancy percentage with $35.7 \%$, respectively, improving the competitive set with $31 \%$, another factor with $6.2 \%$ or the inflation forecast with $4.8 \%$. The study by Jones (2008a) made in the UK showed the data of the previous year (historical operating data) between the information most commonly used to set the annual budget. This study also showed a change in national economic indicators (Jones, 1998), to a greater emphasis on local and regional economic indicators.

In the study by Schmidgall, Borchgrevink \& Zahl-Begnum (1996), approximately $91 \%$ of American hotels and $88.7 \%$ Scandinavian hotels use information from their operating history to project the sales estimates. For U.S. hotels, the most common factor is the local and regional economic indicators, used by $73.6 \%$, while only $49.1 \%$ of Scandinavian hotels use this factor to forecast sales. Another observation is related to the use of information on planning advertising and promotions by $46.3 \%$ of U.S. hotels and only $24.5 \%$ in Scandinavia. The perceived impact on price changes corresponds to $45.1 \%$ and $54.7 \%$, information on national economic level is used at $43.8 \%$ and $54.7 \%$, operational changes suggested by the administrative level at $40.5 \%$ and $18.9 \%$, the impact of expansion (new units) at $29.8 \%$ and $32.7 \%$, and other factors at $13.2 \%$ and $15.1 \%$ of hotels in the United States and Scandinavia, respectively.

The budget period corresponds to the duration or cycle of the budget process. Empirical studies indicate that approximately $74.5 \%$ of hotel companies in Turkey (Uyar \& Bilgin, 2011) and 98.8\% of Greece (Pavlatos \& Paggios, 2009) prepare the budget for one year. Similarly, 91\% of UK hotels set the budget for a period of one year, $4.5 \%$ for six months and $4.5 \%$ for 12 months continuously (continuous budget) (Jones, 1998). In a sequential study by Jones (2008a), the vast majority of organizations use the budget for a period of 12 months, usually considering the fiscal year.

The budget may require revisions over the period due to changes in economic and environmental conditions considering the fiscal year. The hospitality industry may be particularly sensitive to local changes and seasonal fluctuations, for example, weather, terrorist attacks, economic crises, political instability etc.

Just over $70 \%$ of U.S. hotels are reviewing their budgets compared to $44 \%$ in Scandinavia (Schmidgall; Borchgrevink \& Zahl-Begnum, 1996). The review process begins in less than three months into the fiscal year in nearly $62 \%$ of U.S. hotels and a third of Scandinavia. Three to five months for $21.4 \%$ and $45.8 \%$, six to nine months for $9.5 \%$ and $20.8 \%$ in the United States and Scandinavia, respectively, and over nine months for $1.2 \%$ of hotels in the United States.

Next, Schmidgall \& DeFranco (1998) found that in the United States, 21\% conduct the budget review when needed, $40 \%$ monthly, 3\% bimonthly, $16 \%$ quarterly, $12 \%$ semiannually and $4 \%$ in other periods. This corroborates in part with the study of Uyar \& Bilgin (2011) in Turkey, 
diagnosing that $48 \%$ prepare their budget quarterly and $29 \%$ every six months.

Jones (1998) found that in the UK $80 \%$ of hotel companies reviewed the budget, most monthly or quarterly, which corroborates the sequential study by Jones (2008a), which showed statistically that the hospitality industry eventually makes revisions, although this process was not performed routinely, with only $16 \%$ of organizations making revisions to their processes annually.

The results found by Schmidgall, Borchgrevink \& Zahl-Begnum (1996) suggest that budgets are reviewed at a relatively high level in Scandinavia, with $28 \%$ being reviewed at the corporate level and only $3.5 \%$ in U.S. hotels. In the U.S., $68 \%$ of operating budgets were revised monthly, compared with $16 \%$ in Scandinavia. The most common response from Scandinavia was that budgets are revised when performance indicates a need, for $52 \%$ of hotels, and for $12 \%$ in the United States.

Schmidgall, Borchgrevink \& Zahl-Begnum (1996) found that the management level responsible for the budget review can highlight the level of the hotel with $75.3 \%$ in the United States and $52.0 \%$ in Scandinavia. Other results showed that the corporate level corresponds to $3.5 \%$ and 28.0\%, level between the corporation and the hotel $7.1 \%$ and $0 \%$, department level (within the hotel) of $12.9 \%$ and $12 \%$, and others $1.2 \%$ and $8 \%$ in the USA and Scandinavia, respectively.

The budget review is used to identify corrective action problems (87.2\% and $54.2 \%$ ), generation of new projections for the year end results (73.3\% and $70.8 \%)$, performance measurement (50\% and $12.5 \%)$ and review of pricing plans (15.1\% and $8.3 \%$ ), in the United States and Scandinavia, respectively. When the budget is reviewd, all Scandinavian hotel respondents indicated that it was reviewed for the rest of the year, while $61 \%$ in the U.S.. In the U.S., $15 \%$ of the hotels review the budget only for the next month, and the remaining for another period, such as bimonthly and quarterly.

The budget report period includes the time involved in the generation of reports for monitoring results. The study by Uyar \& Bilgin (2011) indicates that $92.5 \%$ of companies generate monthly reports. The research by Schmidgall, Borchgrevink \& Zahl-Begnum (1996) confirms the trend that U.S. hotel companies prepare their budget processes in $76 \%$ for five or more years. The Scandinavian hotel companies indicated that $29.6 \%$ also prepare the budget for five or more years. The most frequent response from Scandinavia was for a period of three years by $33.3 \%$ and another $22.2 \%$ for two years.

Additionally, the findings by Schmidgall, Borchgrevink \& Zahl-Begnum (1996) show that for the hotels which drew up the budget process for one year, it begins two months prior to the new budget period in 5\% of hotel companies in the United States, $20 \%$ three months prior, $29.2 \%$ four months, $27.5 \%$ five months and $18.3 \%$ six or more months. In Scandinavia, $9.1 \%$ start one month earlier, $12.7 \%$ two months, $34.5 \%$ three months, $20 \%$ four months, $16.4 \%$ five months and $7.3 \%$ six or more months.

Among the items included in the budget package, capital expenditures were mentioned by $87.8 \%$ as the most used, review of the competition (82.9\%), marketing plan (80.5\%), full-time employees and equivalents (70.7\%), salaries of the administration (68.3\%), salary survey (36.6\%) and 
other (17.1\%) (Steed \& Gu, 2009).

Among the types of budget, the highlights are zero-based budget, flexible budget, budgeting by activities and beyond budgeting. Table 2 presents the results of empirical studies in hotel businesses in different parts of the world.

Table 2 - Types of budgets (in percentage)

\begin{tabular}{|c|c|c|c|c|c|c|c|c|c|}
\hline & 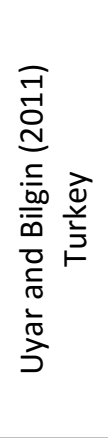 & 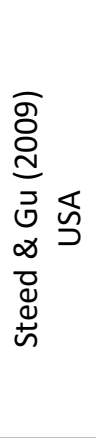 & 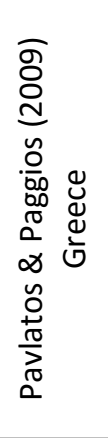 & 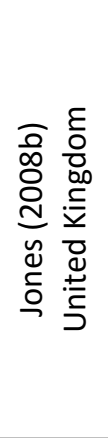 & 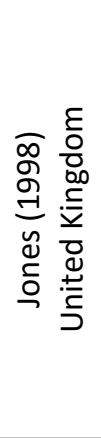 & 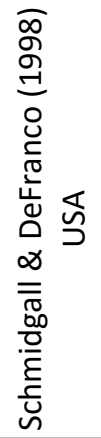 & 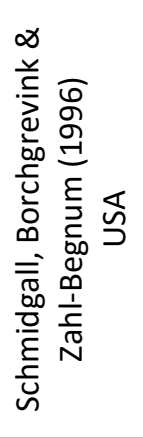 & 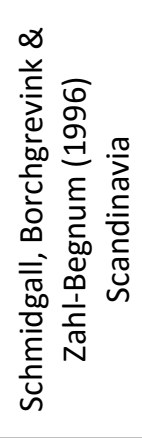 & 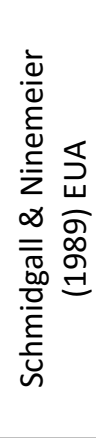 \\
\hline \multicolumn{10}{|l|}{ Corporate budget } \\
\hline Continuous budget & & & & & 4.5 & & & & \\
\hline Zero-based budget & 15 & & 49.4 & & 52 & & 42 & 7 & \\
\hline Flexible budget & 70 & & 15.3 & & 16 & & & & \\
\hline Budget by activities & & & 14.1 & & & & & & \\
\hline Beyond budgeting & & & & & & & & & \\
\hline
\end{tabular}

The zero-based budget is not used routinely in the UK hotel industry. Among the reasons cited it is noteworthy that the hotel business was seen as relatively static and predictable, especially at the unit level (Jones, 2008a).

For the preparation, execution and control of the budget, the hotel could use Excel or their own software. In Turkey, approximately $78.5 \%$ of the companies use Microsoft Excel, $14 \%$ use another software and 6.5\% use Microsoft Excel and another software (Uyar \& Bilgin, 2011). Moreover, Steed \& Gu (2009) describe that the technology used in the budget in the United States includes spreadsheets and transmission in $71.4 \%$ of the hotels, corporate intranet in $16.7 \%$ and others in $11.9 \%$.

Long-term planning can be prepared for different periods. Uyar \& Bilgin (2011), in their study conducted in Turkey, found that $21.5 \%$ use a period of three years, $26.5 \%$ of five years and $12.5 \%$ over five years.

\subsection{Budget Execution}

In implementing the budgetary process, some items have a direct relationship with performance. Research conducted by Uyar \& Bilgin (2011) questioned the following items: the budget is done in secret by top management (3.78), effective leadership is provided in the budget process (4.57), a good flow of information is available for the budget (4.54), coordination between departments is easily achieved (4.22), goals are determined first in the departments and then sub- 
mitted to top management (3.67), goals are determined by top management and then opinions are collected in the departments (3.35) and targets are determined rationally (4.29).

In preparing the budget process, the organization may have different purposes or specific objectives. The study by Jones (1998) conducted in the UK pointed out as specific purposes of the budget: assist in long-term planning with $68 \%$, assist in short-term planning, with $59 \%$, evaluate performance with $93 \%$, coordinate operations with $52 \%$, motivate managers with $77 \%$, communicate plans to employees with $52 \%$ and assist in control with $89 \%$. To Pavlatos \& Paggios (2009), in Greece, the purposes highlighted are in control of costs with $91.8 \%$, coordination activity of the various parts of the organization with $80 \%$ and the performance evaluation of managers appointed by $64.7 \%$ hotels.

To Uyar \& Bilgin (2011), among the purposes of the budget the highlights are expenditure control (4.61), profitability (4.52), assist in long-term planning (4.47), assist in short-term planning (4.34), evaluate the performance (4.29), coordinate operations (4.43), motivate employees (3.81), motivate managers (4.04), communicate plans to employees (3.61). Similarly, for UK hotels, budgets were seen as an operational tool to help managers control operations and keep costs low (Jones, 2008a).

Other purposes can be highlighted as future predictions, maximization of results, introduction of new products and services, planning, control and valuation of the result, and the creation of incentives and rewards.

For budgeting, information can be used from different sources such as results from previous years, statistics and indicators of the industry, market analysis, national, regional and local economic indicators and projections from previous years. To Uyar \& Bilgin (2011), results from previous years (4.57), statistics and indicators of the industry (4.45), market analysis (4.39), national economic indicators (4.29), local and regional economic indicators (4.19), budgeted figures for previous years (4.25) are the most used.

Schmidgall, Borchgrevink \& Zahl-Begnum (1996) found in their study that the information suppliers for budgeting in the United States and Scandinavia were the accounting department, with $68.0 \%$ and $21.8 \%$, controller with $67.2 \%$ and $60.0 \%$, general manager with $51.6 \%$ and $29.1 \%$, assistant manager with $14.8 \%$ and $5.5 \%$, others with $11.5 \%$ and $12.7 \%$ share, respectively.

For the successful use of the budget, one must also consider the human aspects. Yuen (2006) researched in hotels in Macau, China, the effects related to employee satisfaction and participation in the participatory management of the budget process. Among the results of the study is the finding that the greater participation of employees increases responsibility and experiences.

The study by Steed \& Gu (2009) in the United States pointed out that performance bonuses are directly linked to achievement of budget targets $(4,4)$. Other aspects were questioned, such as whether budgetary guidelines were applied to all properties (4.4), whether the budget was used as a standard for performance evaluation (4.1), whether the budget was tied to the strategic plan $(3,7)$ and whether property managers sought the lowest possible goals (3.3).

The results found by Uyar \& Bilgin (2011) in hotels in Turkey corroborate the American 
findings, where the performance bonuses should be linked to the achievement of their budget goals (3.87). Moreover, managers should have clearly defined authority and responsibility for individual control of the budget to work effectively (4.58), participation is key to accept their budgets and consider them attainable (4.45), avoid the so-called "gamesmanship" in which managers try to underestimate revenues and overestimate costs (4.29), the motivation may also be in budgets that are achievable, but difficult to achieve (4.4), and participation in the budget process is critical when budgets are used as a performance measure (4.36).

\subsection{Budget Control}

In control of the budget process specific criteria or points may be used, such as benchmarking or else not using reference points. For those using reference points, this can be done in the form of monetary value, a percentage or repetition of an adverse variable.

While $91 \%$ of Turkish hotels said they use benchmarking, approximately $4 \%$ do not use reference points and $5 \%$ did not answer the question. The most commonly used reference was monetary value with $77 \%$, followed by percentage with $69.5 \%$ and repetition of an adverse variable with 26.5\% (Uyar \& Bilgin, 2011).

In the United States and Scandinavia, the results, according to Schmidgall, Borchgrevink \& Zahl-Begnum (1996), are compared with the original budget at $92.4 \%$ and $72 \%$, with the actual data of the previous year at $86.4 \%$ and $60 \%$, with the budget revised at $45.8 \%$ and $30 \%$, based on expenditures and sales mix values at $25.4 \%$ and $46 \%$, and other factors at $1.7 \%$ and $10 \%$ of the hotels, respectively.

In budgetary control, an important point is the role that monitoring has on the management system of the organization. To Uyar \& Bilgin (2011), the majority of companies surveyed said that the budget is the key performance indicator (47\%), followed by being one of the few key performance indicators (37.5\%) and being little used as a performance measure (10\%).

Among other roles of the budget in control, it can be seen as the primary performance indicator or as one of the few key indicators used. A study conducted in the UK by Jones (2008a) found that a major reason for the use of the budget is to measure the performance, since the hotels indicated that it was seen as the main or one of the few key performance indicators.

To perform this monitoring, different criteria can be used in performance assessment. The study by Uyar \& Bilgin (2011) pointed out that the results of previous years are used in $72 \%$ of Turkish hotels, budgeted figures and industry statistics both with $53 \%$, inter-hotel comparisons with $13 \%$ and balanced scorecard and comparisons with competitors with $16 \%$.

The control requires as input components the appointment of those responsible for assessing the variances of budget reports. Uyar \& Bilgin (2011) researched this point and demonstrated that the general manager with $53 \%$ and top administration with $41 \%$ were the main responsible, next were the heads of departments with $28 \%$, and the budget committees with $33 \%$, in addition to other people responsible with $11 \%$. 
From the comparative analysis of what are the purposes of the analysis of budget variances, hotel companies of Turkey indicated that they were: evaluate the performance of the manager (4.09), evaluate the predictive capability of the person responsible (4.26), control costs and expenses (4.56), timely recognition of a problem (4.55), and feedback to the budget for the next period (4.39) (Uyar \& Bilgin, 2011).

U.S. respondents reported $97 \%$, while $93 \%$ of Scandinavians use budget for control purposes. In the U.S., 72\% of hotel managers are responsible for costs and, in Scandinavia, this number accounts to $65 \%$ (Schmidgall; Borchgrevink \& Zahl-Begnum, 1996).

\section{METHODOLOGY}

This research focuses on the positive theory developed for budgeting in hotels, and such detailed specific subsections of the research (analysis of content, practical research and practical qualitative research) are not widely covered in this article (Jones, 2008).

The number and geographic dispersion of the hotel companies in Brazil have led to selection of tourist destinations. To this end, a survey was conducted in tourist centers, which include the major sites that attract foreign tourists.

The survey applied was developed from the fundamental characteristics identified in the literature review (Schmidgall \& Ninemeier, 1987 and 1989; Schmidgall et al., 1996; Schmidgall \& DeFranco, 1998; Jones, 1998, 2008a and 2008b; Subramaniam et al., 2002; Winata \& Mia, 2005; Yuen, 2006 and 2007; Pavlatos \& Paggios, 2009; Steed \& Gu, 2009; Uyar \& Bilgin, 2011).

From these characteristics the research questions were developed. The application of the survey was conducted in two stages: the first involved the characterization of the hotels located in the tourist centers, including 9 questions; the second involved 15 questions about budget planning, 4 topics regarding the implementation of the budget, using the Likert scale, and 7 objective questions about the assessment and management of organizational performance.

The initial population consists of hotel companies of the tourist centers - Rio de Janeiro (RJ), Florianópolis (SC), São Paulo (SP), Salvador (BA), Foz do Iguaçu (PR), Balneario Camboriu (SC), Porto Alegre (RS), Recife (PE), Fortaleza (CE) and Buzios (RJ) - associated with the ABIH (Brazilian Association of Hotel Industry), for a total of 332 hotels.

For the application of the survey, the first contact with the hotels was made by telephone. If companies were willing to contribute to research, the survey was sent via email to those responsible for the process to collect the information. In this first stage, 264 hotels provided an e-mail address for sending the survey, but 23 were duplicates, and 15 refused to answer. 40 completed surveys were obtained.

\section{RESULTS OF THE STUDY}

\subsection{Characterization of Hotels}


To characterize Brazilian hotels, questions were asked about the category of the organization, which included the following: 5 stars, 4 stars, 3 stars, other and unrated. Furthermore, we questioned the designation used by hotels.

From Table 3, the existence of all categories in the sample can be seen, with low prevalence of one specific category. This is because there are $22 \%$ with 5 stars, 3 stars and unrated. There are still $15 \%$ with other categories, such as luxury and charm.

Table 3 - Information about Brazilian hotels

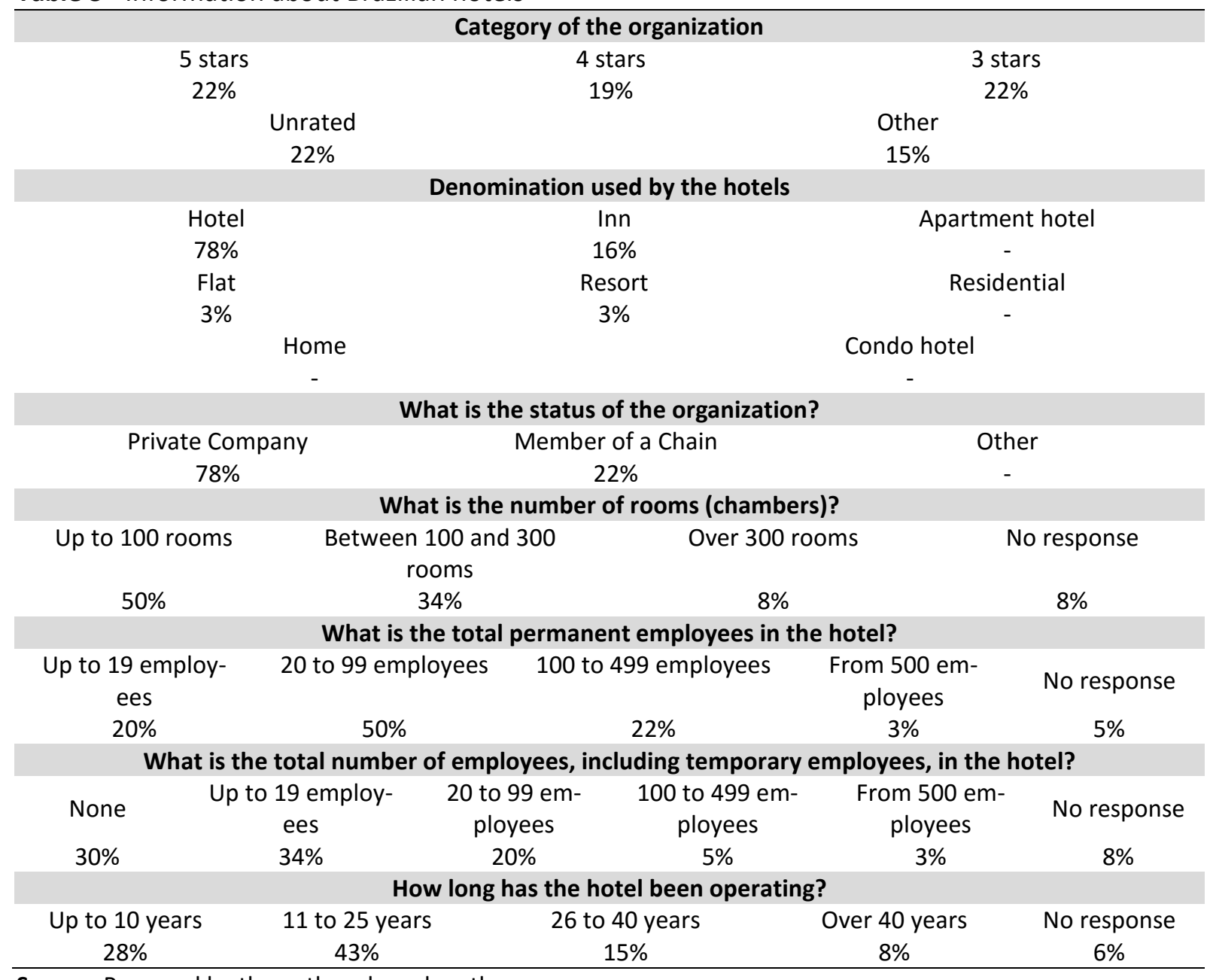

Source: Prepared by the authors based on the surveys

Regarding the name used by the companies, it can be seen that over $70 \%$ of respondents use the nomenclature "hotel". The denomination "inn" was the second most used, representing $16 \%$ of the sample. The study showed the absence of apart-hotels, residential, home and condo hotel.

It appears that most of the organizations surveyed is incorporated as a private company, comprising a percentage of $78 \%$ of the total. The hotels that belong to a chain comprise the other $22 \%$. 
It can be seen that hotels mostly have a capacity of hosting up to 100 rooms, $34 \%$ of them have between 100 and 300 rooms, while only $8 \%$ have more than 300 rooms.

Therefore, this information reflects the number of constant employees in each organization, with or without hiring temporary employees. Thus, it appears that due to the dominance of a small number of rooms, $34 \%$ of hotels have up to 19 temporary employees. Only $3 \%$ of the sample reported having more than 500 permanent employees.

Moreover, it can be seen that $43 \%$ of the selected hotels have between $11-25$ years of experience in the hotel business, while only $8 \%$ claim to have it open for operation for over 40 years.

Table 4 allows to visualize the average occupancy rate of hotels in Brazil in the range from $20 \%$ to $95 \%$, and the approximate amount of beds in each company.

Table 4 - Average occupancy rate and number of beds

\begin{tabular}{ccc}
\hline & Average occupancy rate of the hotels in the sample & \\
$80 \%$ to $95 \%$ & $65 \%$ to $79 \%$ & $55 \%$ to $64 \%$ \\
$16 \%$ & $23 \%$ & $38 \%$ \\
$45 \%$ to $54 \%$ & $35 \%$ to $44 \%$ & $20 \%$ to $34 \%$ \\
$10 \%$ & $10 \%$ & $3 \%$ \\
& Number of beds in Brazilian hotels & \\
12 to 40 beds & 40 to 80 beds & 80 to 150 beds \\
$9 \%$ & $18 \%$ & $13 \%$ \\
150 to 300 beds & 300 to 900 beds & Over 900 beds \\
$34 \%$ & $23 \%$ & $3 \%$ \\
\hline
\end{tabular}

Source: Prepared by the authors based on the surveys

The average occupancy rates show that there is a wide variation, from $20 \%$ to $95 \%$. Most hotels are in the average occupancy rate from $55 \%$ to $64 \%$. Only $3 \%$ of hotel companies reported having reduced occupancy from $20 \%$ to $34 \%$.

Most hotels (34\%) reported having between 150 and 300 beds in their structure, followed by $23 \%$ hotels with 300 to 900 beds and $18 \%$ with 40 to 80 beds. There was great diversity as to the response to the amount of beds, so that all options were met, including that which indicates the amount above 900 beds, confirmed by only one hotel in the sample.

\subsection{Budget Planning}

The results from this item are related to the first stage of the budget process, namely, budget planning. In Table 5 are presented different questions applied to hotels related to that step. First, it is noted that $65 \%$ of the hotels in the sample said they did not use a guide for preparing the budget.

As for the program used to prepare the budget process, 35\% reported using only the Microsoft Excel tool, another 35\% use another tool besides Excel and only 5\% use only the corporate internet. Similarly, in Turkey, 78\% of businesses use Microsoft Excel and 6.5\% use Microsoft Excel and another software (Uyar \& Bilgin, 2011), while in the United States $71 \%$ use spreadsheets and transmission and $16.7 \%$ the corporate internet (Steed \& Gu, 2009). 
It appears that hotel companies do not usually create a budget committee, since $45 \%$ of the respondents have one. On the other hand, in the region of Antalya, in Turkey, the committee and budget manual are common in hotels, according to Uyar \& Bilgin (2011).

Additionally, it is identified that the time spent preparing the budget is usually short, involving less than 40 hours in $40 \%$ of the hotels. Only $13 \%$ reported using $81-120$ hours and $13 \%$ over 120 hours for preparation.

Table 5 - Characteristics of the budget process

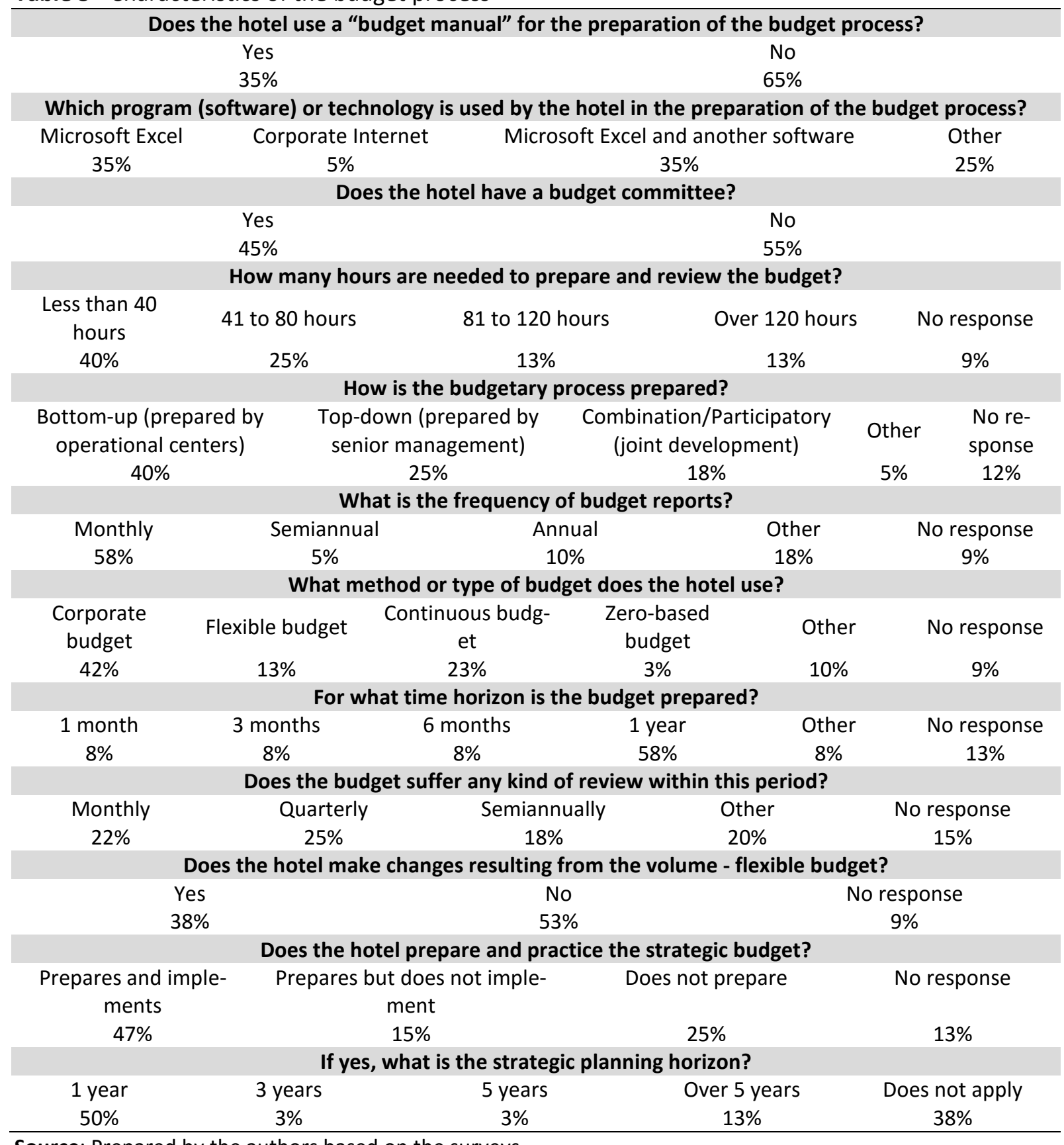

Source: Prepared by the authors based on the surveys

The budgeting process in the Brazilian hotel industry is primarily prepared in bottom-up 
(40\%), top-down (25\%) and combination/participatory (18\%). These results corroborate those found by Schmidgall \& Ninemeier (1987) and by Schmidgall, Borchgrevink and Zahl-Begnum (1996), in the United States and in Scandinavia, respectively, where the bottom-up practice is also used by the large majority.

In contrast, Uyar \& Bilgin (2011) observed differences in Turkey, as Steed and Gu (2009) obtained the same conclusion in the United States, that most hotels use the combination/participatory approach.

In general, Brazilian hotels use corporate-type budget, with $42 \%$ of the sample, prepared for the period of 1 year (58\%). Just as Schmidgall \& DeFranco (1998) in the United States, Jones (1998) in the UK, Uyar \& Bilgin (2011) in Turkey, it was also found that most hotels prepare the budget for the period of 1 year.

Also in relation to budget types, the results show low use of methods such as zero-based and flexible budgeting. Compared to studies by Jones (1998 and 2008b) conducted in hotels in the UK, where the flexible budget is little used, the zero-based budget is applied to half of the companies surveyed, decreasing slightly in the second study. Likewise, Pavlatos \& Paggios (2009) conducted studies in Greece and found that the use of zero-based budget is significant, while the application of the flexible budget and activities is quite low.

With respect to budget review, the results were distributed among the alternatives. But $25 \%$ are revised quarterly, $22 \%$ monthly and $18 \%$ every six months. Furthermore, $53 \%$ of respondents reported not making changes resulting from the volume, while $38 \%$ make adjustments due to variations in occupancy levels. Also according Uyar \& Bilgin (2011) in Turkey and Jones (1998 and $2008 b$ ) in the UK, the revisions are in most cases quarterly.

As for strategic budget, it is made by $62 \%$ of the hotels, with $47 \%$ preparing and implementing it and $15 \%$ only preparing it. For those that prepare the budget, there was a predominance of $50 \%$ for a 1 year horizon.

The research shows that the majority of the Committee is comprised of the general manager/director of the hotel, with $88 \%$. But in $69 \%$ of cases the owners are present, in $56 \%$ the financial manager/treasurer, as well as the accounting manager/controller in $50 \%$ as part of that Committee.

We note that $47 \%$ of the hotels determine the increase in revenue based on the percentage increase over the previous year. Furthermore, 37\% reported having their guidelines based on occupancy rate and only $3 \%$ on a statistical method. Steed \& Gu (2009) found that in the United States, in addition to the guidelines being based on the percentage increase over the previous year, REVPAR (percentage increase) is also used for the definition of revenue growth.

It can be noted that the most common budget package for hotels is the marketing plan (42\%), followed by capital expenditures (37\%) and management salaries report (37\%). The other features achieved the same percentage of utilization, that is, $21 \%$ of the times present in the composition. Now in the work by Steed \& Gu (2009), capital expenditures (87\%), assessment of competitors (83\%) and the marketing plan (81\%) were identified for hotels in the United States as the 
most common.

\subsection{Budget Execution}

Among the results obtained in relation to the implementation of the budget, $61 \%$ indicate that effective leadership is provided in the budget process and there is a good flow of information, and that $50 \%$ of respondents strongly agree that coordination between departments is easily achieved, as presented in Table 6.

Table 6 - Results of budget implementation

\begin{tabular}{|c|c|c|c|c|c|}
\hline BUDGET EXECUTION & $\begin{array}{l}\text { Totally } \\
\text { Disagree }\end{array}$ & $\begin{array}{l}\text { Partly Disa- } \\
\text { gree }\end{array}$ & Indifferent & Partly agree & $\begin{array}{l}\text { Totally } \\
\text { Agree }\end{array}$ \\
\hline $\begin{array}{l}\text { Budget is considered a secret of } \\
\text { top management }\end{array}$ & $18 \%$ & $5 \%$ & $11 \%$ & $16 \%$ & $37 \%$ \\
\hline $\begin{array}{l}\text { Effective leadership is provided in } \\
\text { the budget process }\end{array}$ & $8 \%$ & $3 \%$ & $8 \%$ & $8 \%$ & $61 \%$ \\
\hline $\begin{array}{l}\text { A good flow of information is } \\
\text { available for the budget }\end{array}$ & - & $3 \%$ & $3 \%$ & $21 \%$ & $61 \%$ \\
\hline $\begin{array}{l}\text { Coordination between depart- } \\
\text { ments is easily achieved }\end{array}$ & $11 \%$ & $8 \%$ & $5 \%$ & $13 \%$ & $50 \%$ \\
\hline $\begin{array}{l}\text { Goals are determined first in the } \\
\text { departments and then submitted } \\
\text { to senior management }\end{array}$ & $42 \%$ & $5 \%$ & $18 \%$ & $11 \%$ & $11 \%$ \\
\hline $\begin{array}{l}\text { Goals are determined by top man- } \\
\text { agement and then opinions are } \\
\text { collected in the departments }\end{array}$ & $5 \%$ & $16 \%$ & $13 \%$ & $21 \%$ & $32 \%$ \\
\hline $\begin{array}{l}\text { Goals are the result of a structured } \\
\text { process and aligned with the Stra- } \\
\text { tegic Planning }\end{array}$ & $5 \%$ & - & $11 \%$ & $24 \%$ & $47 \%$ \\
\hline $\begin{array}{l}\text { Information used in the budget } \\
\text { preparation are: }\end{array}$ & Always & $\begin{array}{l}\text { Almost al- } \\
\text { ways }\end{array}$ & Eventually & Almost never & Never \\
\hline $\begin{array}{l}\text { Results from previous years - per- } \\
\text { formed }\end{array}$ & $50 \%$ & $13 \%$ & $5 \%$ & $3 \%$ & - \\
\hline Industry statistics/indicators & $24 \%$ & $13 \%$ & $11 \%$ & $3 \%$ & $16 \%$ \\
\hline Market analyzes & $39 \%$ & $16 \%$ & $5 \%$ & $3 \%$ & $5 \%$ \\
\hline National economic indicators & $45 \%$ & $8 \%$ & $8 \%$ & $8 \%$ & $3 \%$ \\
\hline Figures from previous years & $29 \%$ & $13 \%$ & $3 \%$ & - & $3 \%$ \\
\hline $\begin{array}{l}\text { Local or regional economic indica- } \\
\text { tors }\end{array}$ & $39 \%$ & $5 \%$ & $13 \%$ & $3 \%$ & $5 \%$ \\
\hline
\end{tabular}

Source: Prepared by the authors based on the surveys

The research shows that for the vast majority of respondents the goals intended with budgeting are to maximize the results, plan, monitor and appraise the results and assist in shortterm budget control, which corroborates with the research by Uyar \& Bilgin (2011) in hotels in the Antalya region in Turkey.

With regard to the information used in the preparation of the budget, it can be observed that statistical information had a lower utilization in the hotels surveyed. Thus, research shows that budgets are more frequently prepared using the results from previous years and economic 
indicators.

On the analysis of motivational aspects, it is observed that it is more related to authority, individual manager responsibility and participation in the development and achievement of goals planned with the budget, which reinforces the results found by Umapathy (1987), on practices that make budget systems more effective.

\subsection{Budget Control}

The results indicate, as shown in Table 7, that few of the hotels surveyed use th tools proposed by Benchmarking ( $8 \%$ ) in the budget evaluation. The form used is $63 \%$ concentrated in reference points that mostly uses the percentage. Similar to the studies by Jones $(1998,2008 a, b)$ carried out in hotel companies in the UK, the results obtained in this study show that the role of the budget in monitoring the actual performance of the organization is the main performance indicator.

Table 7 - Budget Control

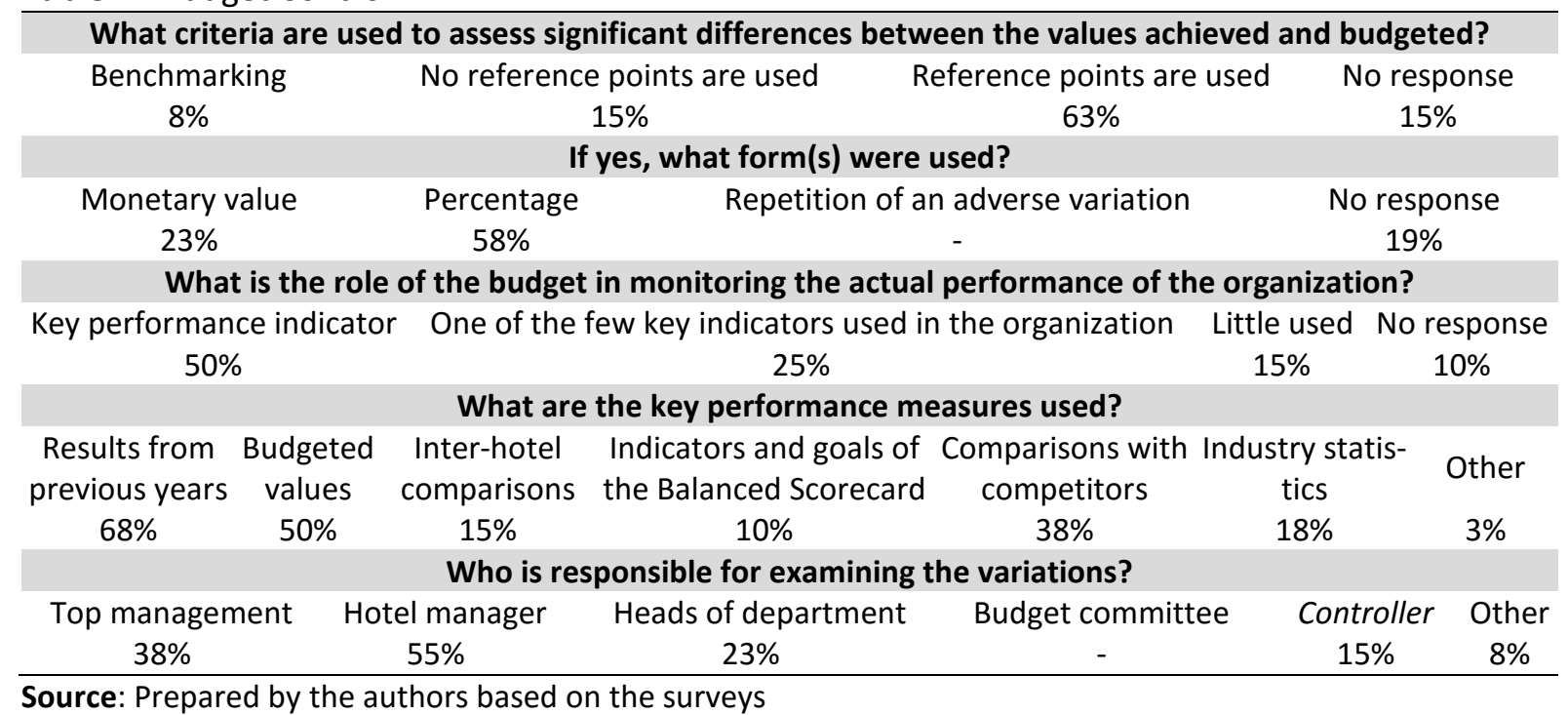

Source: Prepared by the authors based on the surveys

Among the key performance measures used are: the results of previous years with $68 \%$, budgeted amounts with $50 \%$ and also the comparison with competitors with $38 \%$. Among the response options, the Balanced Scorecard received the lowest indication (10\%), which indicates possibly a lack of knowledge and non-use by managers of this tool for performance evaluation.

As highlighted in the study by Schmidgall, Borchgrevink \& Zahl-Begnum (1996), one of the leading practices in relation to the adoption of a budget is to analyze the variations, which will bring to the company the ability to implement corrective actions on the problems detected. For the Brazilian hotel industry, the analysis of variations is aimed potentially to the hotel manager (55\%) and top management (39\%).

The analysis of variation is done on a monthly basis for $62 \%$ of the cases, as presented in Table 8 . The goals are directed at controlling costs/expenses (74\%), as proved by the research by 
Schmidgall, Borchgrevink \& Zahl-Begnum (1996) in their comparison of hotel companies in the United States and Scandinavia. Other highlights are the identification of a potential problem in time to avoid it and providing feedback to the next period budget, the percentage of agreement being $62 \%$ and $53 \%$, respectively.

Table 8 - Analysis of variation

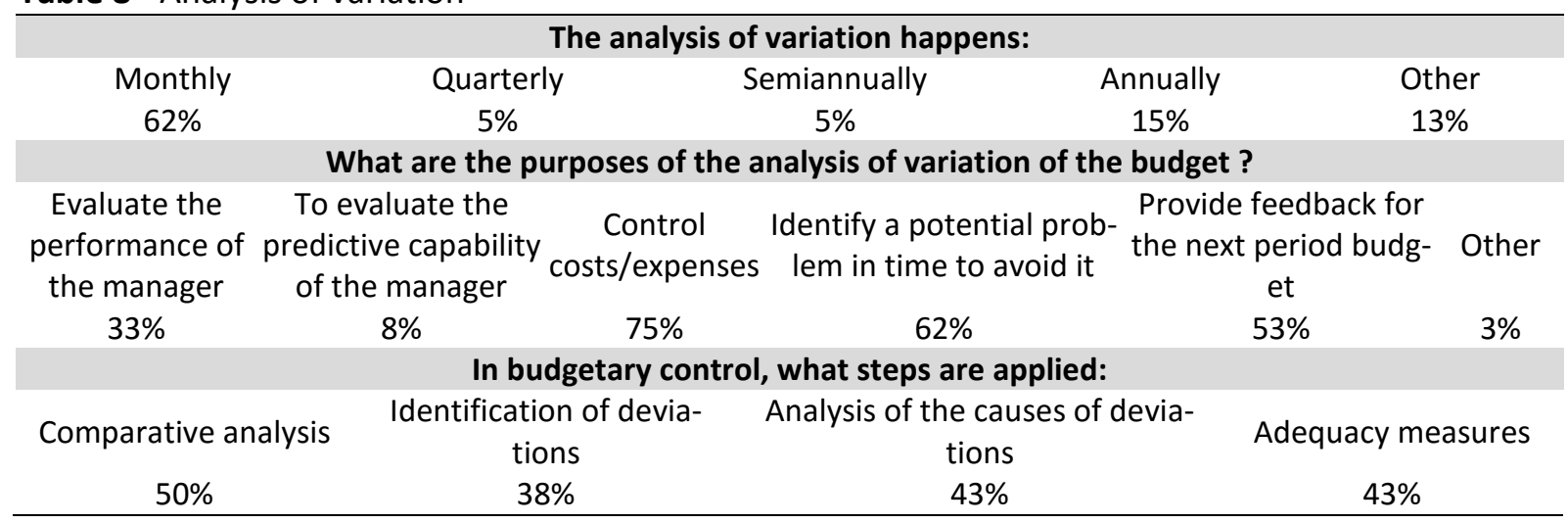

Source: Prepared by the authors based on the surveys.

With the purpose of budgetary control, the step further applied in hotels of the research is the comparative analysis (50\%). The analysis of the causes of the deviations and adequacy measures, both with $43 \%$, also appear as steps very often applied in control.

In closing, it can be noted, as in previous studies in other countries, that in the hotels of this research the budget is widely used as one of the most important tools for managers regarding planning and control (Abdel-Kader \& Luther, 2006; Uyar, 2009; Sivabalan et al., 2009; Libby \& Lindsay, 2010; Ostergren \& Stensaker, 2011; Uyar \& Bilgin, 2011).

\section{DISCUSSIONS AND CONCLUSIONS}

We conclude that the goal of this Article has been reached, considering that the questionnaires allowed to explore the budgeting practices in the hotel industry of Brazil's main tourist centers. It was possible to characterize these hotels as well as analyze the planning, execution and control of the budget.

It was noted that the classification adopted by most hotels is the denomination "hotel". The "inn" was the second most commonly used nomenclature, representing $16 \%$. Furthermore, $78 \%$ of the hotels in the sample are constituted in the form of private company.

It appears that most of the hotels has fewer than 100 rooms per unit and 20-99 employees. Predominantly, respondents reported that hotels have between 150 and 300 beds in one unit.

The budget process most widely used is the bottom-up, which is consistent with the results found by Schmidgall \& Ninemeier (1987) in the United States and Schmidgall et al. (1996) in the United States and Scandinavia. In the UK, Jones (2008b) concluded that none of the approaches (bottom-up, top-down and combination/participatory) was predominant. Uyar \& Bilgin (2011) and 
Steed \& Gu (2009) observed that in Turkey and the United States, respectively, most hotels use the combination/participatory approach.

Previous studies have provided evidence that the form of budgeting was changing with time, towards a greater participation of employees in the process, although this research conducted in Brazil confirms that there is still a great centralization of the budget process in the top management of the hotel.

It was found that it is not a common practice to create a budget Committee in Brazilian hotels (42\%) nor to use a budget manual (32\%). However, Uyar \& Bilgin (2011) found that, in Turkey, the committee and budget manual are common in the hotel industry.

With regard to the information used in the preparation of the budget, it can be observed that statistical information had a lower utilization in the hotels surveyed. Thus, research shows that budgets are more frequently prepared using the results from previous years and economic indicators. However, Steed \& Gu (2009) realized that in U.S. hotels, the guidelines are based on REVPAR (percentage increase) and the percentage increase over the previous year.

In general, the survey results denote that the budget in hotel companies in Brazil is still underutilized, with partial implementation of many of its features and techniques. Still, there is a lack of some of the practices highlighted by Umapathy (1987), which according to the author are key in the implementation of the budget process and adopted by successful companies.

Regarding practical contributions of this study, several aspects that can improve the budgeting process in the hotels surveyed were pointed out, such as the creation of a committee, greater involvement of people and implementation of incentive systems to motivate them.

Although the flexible budget is recommended for use in this market segment, the survey showed that $42 \%$ of hotels use the corporate budget. There are discussions on this subject, but corporate budget still remains widely used in organizations (Jones, 2008a; Uyar \& Bilgin, 2011), as seen in this and other similar studies.

For further research, it is suggested that budgetary practices from other countries and continents are observed. Additionally, it is recommended to analyze questions about the practices of the capital budget and the environmental performance of hotel companies.

\section{REFERENCES}

Abdel-Kader, M., \& Luther R. (2006). Management accounting practices in the British drink and food industry. British Food Journal. 108(5), 336-357.

Castro, J. K., Souza P., Santos, G. R., \& Lunkes, R. J. (2012). Prácticas presupuestarias aplicadas a las empresas hoteleras de Brasil: Un studio en la ciudad de Florianópolis. Estudios y Perspectivas en Turismo. 21, 904924.

De Waal, A., Hermkens-Janssen, M., Van De Ven, A. (2011). The evolutionary adoption framework: Explaining the budgeting paradox. Journal of Accounting and Organizational Change. 7(4), 316336. 
Embratur. (2013). Instituto Brasileiro de Turismo. Retrieved on 10 november, 2014, <http://www.turismo.gov.br/turismo/o_ministerio/embratur/>.

Hope, J., Fraser, T., \& Rosen, C. (2003). Trash the budget. Optimize February. 2, 24-31. Horngren, C. T., Foster, G., \& Datar, K. M. (2000). Contabilidade de Custos. LTC, Rio de Janeiro.

Jones, T. A. (1998). UK hotel operators use of budgetary procedures. International Journal of Contemporary Hospitality Management. 10(3), 96-100.

Jones, T. A. (2008a). Improving hotel budgetary practice-A positive theory model. International Journal of Hospitality Management. 27(4), 529-540.

Jones, T. A. (2008b). Changes in hotel industry budgetary practice. International Journal of Contemporary Hospitality Management. 20(4), 428-444.

Libby, T., \& Lindsay, R. M. (2010). Beyond budgeting or budgeting reconsidered? A survey of North-American budgeting practice. Management Accounting Research 21: 56-75.

King, R., Clarkson, P. M., \& Wallace, S. (2010). Budgeting practices and performance in small healthcare businesses. Management Accounting Research. 21(1), 40-55.

Ministry of Tourism. (2010). Dados do turismo brasileiro. Retrieved on 20 october, 2014, <http://www.turismo.gov.br/export/sites/default/turismo/o_ministerio/publicacoes/down loads_publicacoes/Cartilha-Dados_Turismo-15x21-web.pdf>.

Ministry of Tourism. (2013). Estrangeiro que visita o Brasil deseja voltar. Retrieved on 13 november, 2014, <http://www.turismo.gov.br/turismo/noticias/todas_noticias/20130828.html>. Pavlatos, O., \& Paggios, I. (2009). Management accounting practices in the Greek hospitality industry. Managerial Auditing Journal. 24(1), 81-98.

Schmidgall, R. S., Borchgrevink, C. P., \& Zahl-Begnum, O. H. (1996). Operations budgeting practices of lodging firms in the United States and Scandinavia. International Journal of Hospitality Management. 15(2), 189-203.

Schmidgall, R. S., \& Defranco, A. L. (1998). Budgeting and forecasting: Current practice in the lodging industry. Cornell Hotel and Restaurant Administration Quarterly. 39(6), 45-51.

Schmidgall, R. S., \& Ninemeier, J. (1987). Budgeting in hotel chains: coordination and control. The Cornell Hotel and Restaurant Administration Quarterly. 28(1), 79-84.

Schmidgall, R. S., \& Ninemeier, J. (1989). Budgeting practices in lodging and food service chains: an analysis and comparison. International Journal of Hospitality Management. 8(1), 35-41.

Sivabalan, P., Booth, P., Malmi, T., \& Brown, D. A. (2009). An exploratory study of operational reasons to budget. Accounting and Finance. 49(4), 849-871.

Steed, E., \& Gu Z. (2009). Hotel management company forecasting and budgeting practices: A survey-based analysis. International Journal of Contemporary Hospitality Management. 21(6), 676-697. 
Subramaniam, N., McManus, L., \& Mia, L. (2002). Enhancing hotel manager's organizational commitment: An investigation of the impact of structure, need for achievement and participative budgeting. International Journal of Hospitality Management. 21(4), 303-320.

Uyar, A. (2009). An evaluation of budgeting approaches: traditional budgeting, better budgeting, and beyond budgeting. Journal of Academic Studies. 11(42), 113-130.

Uyar, A., \& Bilgin, N. (2011). Budgeting practices in the Turkish hospitality industry: An exploratory survey in the Antalya region. International Journal of Hospitality Management. 30(2), 398-408.

Winata, L., \& Mia, L. (2005). Information technology and the performance effect of managers' participation in budgeting: Evidence from the hotel industry. International Journal of Hospitality Management. 24(1), 21-39.

Yuen, D. (2006). The impact of a budgetary design system: direct and indirect models. Managerial Auditing Journal. 21(2), 148-165.

Yuen, D. (2007). Antecedents of budgetary participation: enhancing employees' job performance. Managerial Auditing Journal. 22(5), 533-548.

Artigo recebido em: 06/01/2014. Artigo aprovado em: 11/11/2015. 